\title{
Thoracic and lumbar intraspinal tumours associated with increased intracranial pressure
}

\author{
FRANZ E. GLASAUER ${ }^{1}$ \\ From the Department of Neurosurgery, U.S. Naval Hospital, National Naval \\ Medical Center, Bethesda, Maryland, U.S.A.
}

It is easy to comprehend that spinal cord tumours located in the cervical region or the cervico-cranial junction can produce symptoms of increased intracranial pressure by mechanical obstruction of the spinal fluid pathway. It is more difficult to rationalize, however, the occurrence of these symptoms with tumours in the thoracic and lumbar spine. The rarity of this incidence is supported by the fact that only 19 cases were found in the literature. One such case encountered by the author prompted the present report. The pertinent and interesting findings associated with it and those from the literature will be discussed.

CASE REPORT

This 17-month-old white baby girl (N.N.M.C. No. 153203 FJM) was admitted to the National Naval Medical Center on 10 September 1948. Five weeks before admission the child was thrown forward while riding in a car but sustained no obvious injuries. Several days later she became fretful and irritable, and was referred to a local hospital. Cervical spine films were interpreted as minimal dislocation of $C_{4}$ and $C_{5}$. At lumbar puncture the spinal fluid was pinkish-xanthochromic with an increased protein content. She was placed in cervical traction for two weeks.

A month before the automobile accident, the mother had noticed weakness in the child's right leg and urinary hesitancy. While in cervical traction, this weakness and a foot drop became more evident and prompted her transfer.

On examination, the tendon reflexes and sensation were normal. The right leg was weak with loss of spontaneous movements. On several occasions a right ankle clonus was elicited. A lumbar puncture revealed an opening pressure of $135 \mathrm{~mm}$. of water, the fluid was xanthochromic, and clotted spontaneously. The protein content was $2,200 \mathrm{mg}$. per $100 \mathrm{ml}$. Repeat spine films showed only a slight scoliosis to the left in the thoracolumbar area.

A myelogram disclosed a complete block of the dye column with an irregular outline at the $L_{1}$ vertebra. A

${ }^{1}$ Present address: Department of Neurosurgery, Edward J. Meyer Memorial Hospital, Buffalo, New York. laminectomy was carried out and at the level of $T_{10}$ to $L_{1}$ an oval-shaped, discoloured area was exposed which was soft to palpation and quite well demarcated from the adjacent compressed spinal cord. According to the operation note the tumour was completely removed. The histology of the tumour was of a fibrillary astrocytoma (Fig. 1).

The child's post-operative course was uneventful and at her discharge in November 1948 her right leg was still weak. Sensation was intact and the reflexes in the right leg were diminished. She was started on an intensive programme of physical therapy until she was able to walk unassisted.

She was re-admitted on 27 April 1949 with complaints of pain in her thighs and frequent spasms of both legs. There was some atrophy of her right calf. She had good bowel and bladder control. With the improvement in walking, the scoliosis had progressed. The spine films showed marked scoliosis with its convexity to the left in the thoracic region and a compensatory curve in the lumbar area. She was placed in a plaster body cast.

Several admissions during June 1949 and August 1950 were all primarily for changing and adjusting of her body cast.

At the age of 10 she (N.N.M.C. No. 263470 FJM) was admitted for surgical correction (fasciotomies) of flexion contraction of both hips, followed by further physiotherapy.

In the interval up to her last admission she had no relapse in her neurological condition and was normally active in play and sports.

Her admission on 18 July 1962 (N.N.M.C. J-326590, WJM) was at the age of 15 when she entered with complaints of double vision and headache. Two and a half weeks before admission she developed an upper respiratory infection and experienced mild frontal headaches. Within three to four days, her cold subsided but the headaches persisted. It was most severe in the morning and occasionally awakened her from sleep. She also experienced nausea in the morning but no vomiting. The headaches continued to increase in severity and she noted also a stiffness in her legs. Twelve days before admission, she noticed for the first time double vision which remained.

Examination revealed a marked thoracic kyphosis and tenderness over the surgical scar. The reflexes were equal but more active in the lower limbs with the plantar response extensor on the left and equivocal on the right. 


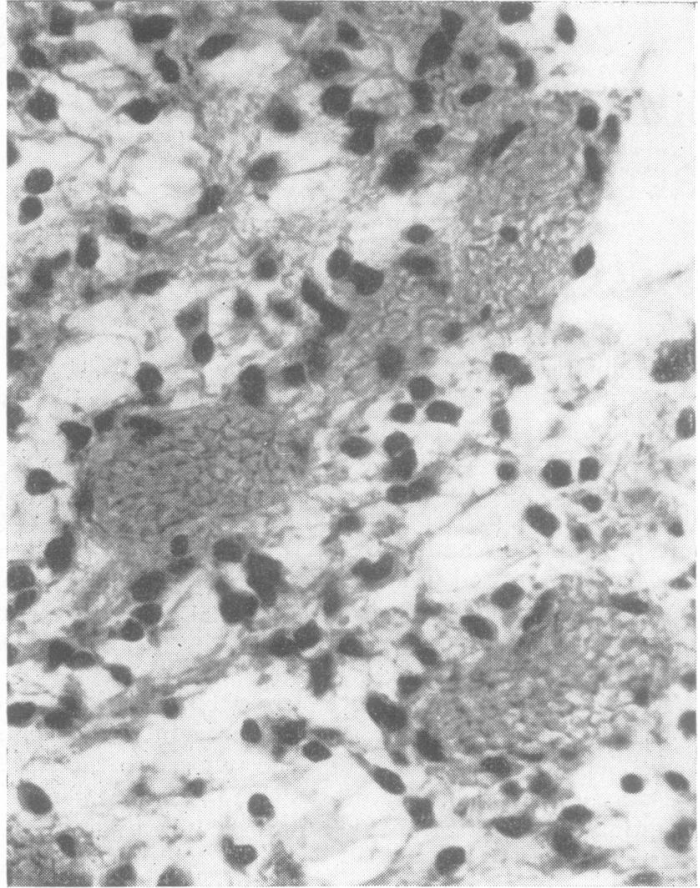

FIG. 1 .

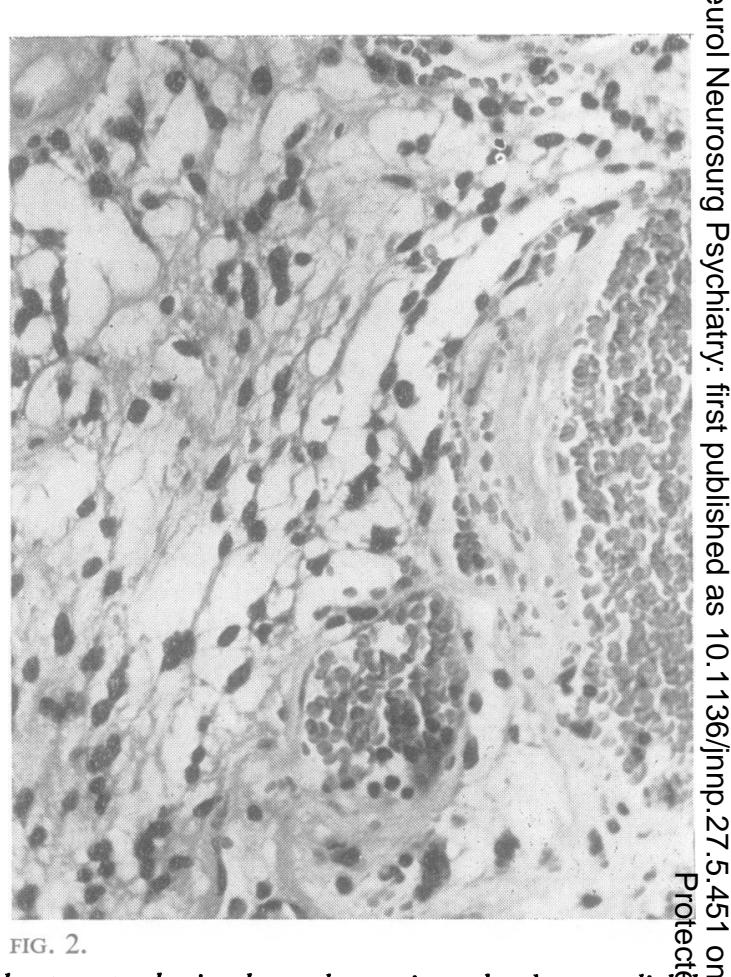

FIG. 2

FIG. 1. Section of the tumour reveals irregularly arranged astrocytes having hyperchromatic and only very sligh ${ }_{-1}$ pleomorphic nuclei. There are abundant fibrillar cytoplasmic processes on these cells which interlace, forming a loeseO meshwork through which dilated vascular spaces are seen to course. Diagnosis is fibrillar astrocytoma. Haema toxylin and eosin $\times 341$.

FIG. 2. Examination of the most recent biopsies reveal a tumour again composed of astrocytes very similar to these seen in the original specimen in 1948. The only significant point of difference is the increased vascularity of the la $\vec{s} \overrightarrow{0}$ biopsy. Diagnosis is astrocytoma. Haematoxylin and eosin $\times 209$.

Sensation to touch and pin prick was diminished over the right thigh and lateral calf. Position sense was poor in the right toe and fair in the left one. There was marked weakness of the right foot with spasticity in both legs. Her gait was spastic with circumduction. On fundoscopy the disc margins were blursed with small flame-shaped haemorrhages and exudate in the right. The right pupil was slightly larger but both reacted promptly. There was a right sixth nerve palsy with diplopia. The remaining cranial nerves were intact.

A lumbar puncture revealed an opening pressure of $360 \mathrm{~mm}$. and the fluid was grossly bloody and xanthochromic. Skull films showed increased digital markings indicative of increased intracranial pressure. Thoracolumbar spine films showed marked lumbar lordosis and mid-thoracic kyphoscoliosis with anterior wedging of the bodies of $T_{7}$ and $T_{8}$, and evidence of a laminectomy from $T_{5}$ to $T_{12}$.

As her presenting symptoms and findings were those of increased intracranial pressure rather than related to the spine, attention was focused on the cranium. A right carotid arteriogram disclosed straightening and stretching of the anterior cerebral artery suggestive of dilated lateral ventricles, but no shift or abnormal vessels. Three days later, a pneumoencephalogram was carried out and the spinal fluid was again noted to be bloody and xantho chromic. On several occasions during the injection of aisD she complained of pain in her back. The study showed mild dilatation of the ventricular system without shift or displacement. Following this, Pantopaque was injected in the lumbar subarachnoid space and a block was con? firmed at $T_{9}$ and $T_{10}$. The block remained unchanged in. prone or supine position but in the lateral position the dye advanced slightly craniad. During myelography? whenever the dye encountered the area of obstruction; she experienced the same pain noted earlier during the injection of air. The spinal fluid contained gross bloof̧ with $75 \%$ of the red cells crenated. The protein contene was $360 \mathrm{mg}$. per $100 \mathrm{ml}$. The other cerebrospinal fluid findings were normal. An E.E.G. recorded minimaP electric abnormalities. A brain scan with R.I.S.A. was normal.

On 27 July 1962, under general anaesthesia, the previous laminectomy site was reopened and the durd found closed. No obvious subarachnoid space was en countered, instead a yellowish, soft tissue at the craniag 
part and brownish, cystic tissue in the caudad part of the exposure. The upper part appeared to contain the spinal cord anteriorly and from the lower right of the exposure a bluish-red nodule was enucleated. The tumour extended craniad and without a definite cleavage plane. Brownish, multiple cysts were stripped from the inner surface of the dura. No healthy spinal cord or nerve root could be identified. An attempt to pass a no. 8 French rubber catheter in each direction was met with resistance. Considering the extreme tumour involvement and its lack of demarcation and the relative good function of the patient, no further attempt was made to remove the tumour. The dura was left open and the incision closed in layers. The histology of the tumour was similar to that removed 14 years before and diagnosed as astrocytoma, grade I (fibrillar) (Fig. 2).

Post-operatively the girl's spasticity and sensory loss increased. After three days her headaches had considerably lessened but diplopia persisted. She was able to walk with assistance and had no urinary difficulty. Within five days the headaches had completely disappeared and papilloedema was receding. Since her cranial symptoms improved, it was postulated that the spinal pathology alone was responsible for the headaches, the sixth nerve palsy, and the papilloedema. On 10 August, radiation therapy to the thoraco-lumbar spine was started and she received a total of $4,500 \mathrm{r}$. within a period of 46 days. Physiotherapy and gait training was resumed. At discharge, on 14 September 1962, there was no evidence of papilloedema or diplopia. Plantars were extensor bilaterally and the sensory loss was restricted to both anterior thighs. Motor strength had improved and although her gait was spastic, she was able to walk without help.

When the follow-up examination was made in July 1963, she had returned to school and was able to participate in her outside activities as previously. She had no headaches or recurrence of diplopia, no back or leg pain, but increased tightness in the legs when tired. Examination revealed hyperactive reflexes and ankle clonus in both legs. The plantar was extensor on the left and equivocal on t'e right. The area of diminished sensation was smaller but associated with dysaesthesia. Vibratory sense was equal, however, position sense was poor in both big toes, more so on the left. Motor strength was excellent with only slight weakness in dorsiflexion of the right foot. Her gait was spastic and slightly ataxic with a tendency of adduction of the thighs. The area of incision was tender. The fundi were normal; the pupils were equal and no diplopia was elicited.

At lumbar puncture the pressure measured $160 \mathrm{~mm}$. The spinal fluid was colourless, without cells, and a protein content of $150 \mathrm{mg}$. per $100 \mathrm{ml}$.

In summary, she showed steady and favourable improvement and the cranial symptoms had completely disappeared. She is continuing her activities, which include swimming, bicycling, and specific exercises.

\section{ANALYSIS}

As emphasized in the introduction, the case reports in which tumours of the cervical cord were respon- sible for symptoms of increased intracranial pressure were excluded as they represented a somewhat different entity. All reports of tumours originating in the thoracic and lumbar spine associated with symptoms of increased intracranial pressure and their important data are summarized in Table $I$.

Two reports, one by Abbott (1939) and the other by Fincher (1951), were purposely included with due consideration as they were originally reported as representing the syndrome of spinal subarachnoid haemorrhage associated with spinal cord tumours. Abbott's case recorded headaches, dilated ventricles on pneumoencephalography, and bloody spinal fluid. Headaches, blurred vision, and the findings of papilloedema with haemorrhage were presented in Fincher's case 5. Their spinal fluid findings included xanthochromia, blood, and increased pressure, but unfortunately no protein values. Therefore, their symptoms and findings could well have been caused by the presence of the tumour with its spinal fluid changes instead of being attributed to the spinal subarachnoid haemorrhage. The case quoted by Kyrieleis (1931) was omitted from the table for lack of pertinent information.

SEX AND AGE Among the 20 patients studied, 12 were women and eight men. The average age was 30 years with a range from 9 to 69 years. There were six children under the age of 16 , representing onethird of the series. Considering the occurrence in decades, nine were in the first two decades, four in the third, and five in the fourth representing most of the cases.

CEREBRAL SYMPTOMS AND FINDING; These are set out in Table II. It was of particular interest that kyphosis, scoliosis, or increased lordosis occurred in only four patients, all under the age of 18 years.

CRANIAL FINDINGS On plain skull films, three times separation of cranial sutures was noted and as frequent increased digital markings. Erosion of the dorsum sellae was present in two cases and two skull films were normal. On pneumoencephalography or ventriculography various degrees of ventricular dilatation up to gross hydrocephalus was found in 11 of the 20 cases. One air study was normal. Carotid arteriography was carried out in two cases and revealed stretching of the cerebral vessels consistent with dilatation of the ventricular system. One vertebral arteriogram was considered normal. At surgical exploration or at necropsy, leptomeningitis was present in two and a fibrous band over the cisterna magna was found in one case.

CEREBROSPINAL FLUID FINDINGS Ventricular fluid was obtained in four cases. Its protein content varied 
TABLE I

PERTINENT DATA FROM CASES OF SPINAL CORD TUMOURS ASSOCIATED WITH INCREASED INTRACRANIAL PRESSURE

Author

Age Sex Cranial Symptoms
(years)

Cranial Findings

Spinal Changes

1 Zeitlin (1937)

2 Abbott (1939)

3 Fincher (1951) (case 5)

4 Love et al. (1951)

5 Love et al. (1951)

6 Love et al. (1951)

7 Rudnicki et al. (1951)

8 Jentzer et al. (1952)

9 Gardner et al. (1954)

10 Weickmann (1954)

11 Beduschi et al. (1955)

12 Rovetta (1957)

13 Farnarier et al. (1957)

14 Halpern et al. (1958)

15 Cecotto et al. (1959)

16 Rohr et al. (1959)

17 Rohr et al. (1959)

18 Teng et al. (1960)

19 Harris (1962)

(case 6)

20 Present case
37

M

16

18

12

44

43

20

36

40

F

69

$\mathbf{M}$

43

$\mathbf{M}$

9

F

F

F

$\mathbf{M}$

$\mathbf{F}$

$\mathbf{F}$

$\mathbf{M}$

$\mathbf{M}$

Headaches

Headache, vomiting

Failing vision

Diminished visual acuity

Vomiting, diplopia

Headache, transient diplopia; $7 \mathrm{mth}$. later headache, vertigo, blurring vision

Headache, vomiting
Papilloedema, unequal pupils

Bilateral choked discs with haemorrhages; $3 \mathrm{mth}$. later clear

Papilloedema 4 D with haemorrhages: $2 \mathrm{mth}$. post-operatively: no atrophy

Papilloedema 4 D; post-operatively: disappeared

Papilloedema 4 D with haemorrhages, bilateral sixth nerve palsy;

$1 \mathrm{mth}$. post-operatively:

papilloedema disappeared

Papilloedema 2 D ? seizure; post-operatively: subsiding

Papilloedema 1-2D with haemorrhages, visual fields constricted;

$3 \mathrm{mth}$. post-operatively: normal

Papilloedema 2 D, diminished visual acuity; $2 \mathrm{mth}$. post-operatively: disappearance, optic atrophy

Papilloedema 2-3 D, diplopia; $6 \mathrm{mth}$. post-operatively: normal

Papilloedema 4-6 D with haemorrhages, enlarged blind spot, regression postoperatively

Papilloedema 2-3D with haemorrhages;

3 weeks: regression

Papilloedema right abducens palsy;

p.o. ventriculostomy:

symptoms subsided

Papilloedema with haemorrhages;

Papilloedema 2 D R

Papilloedema 3 D L with

haemorrhages

Papilloedema with haemorrhages 3 D

Papilloedema 2 D with haemorrhages and venous engorgement enlarged

Headache, vomiting, blurred vision; 2 mth. post-operatively: negative blind spot

Papilloedema with haemorrhages, nystagmus; later, negative

Diminish. lordosis post. scalloping all lumb. verf. larged interpedunc. distance

Headache, vomiting, blurred vision; postoperatively: clear

Papilloedema 2-3D with haemorrhages; Tenderness middorsal to @act V.A. $20 / 40$ disc pale

Papilloedema, right abducens palsy,

Headache, dizziness, occasional vomiting nystagmus to left

Headache, nausea, diplopia
Early papilloedema with haemorrhage, Thoraco-lumbar kyphosc right abducens palsy
Flattening of laminae L1

Scoliosis, erosion of pedictes T12-22

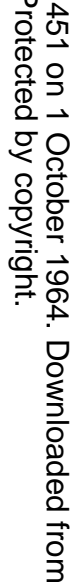
increased lordosis 
TABLE I-continued

PERTINENT DATA FROM CASES OF SPINAL CORD TUMOURS ASSOCIATED WITH INCREASED INTRACRANIAL PRESSURE

erebrospinal Fluid

\begin{tabular}{|c|c|c|}
\hline olour & $\begin{array}{l}\text { Pressure } \\
\left(\mathrm{mm} . \mathrm{H}_{2} \mathrm{O}\right)\end{array}$ & $\begin{array}{l}\text { Proteir } \\
\text { (mg. \% }\end{array}$ \\
\hline $\begin{array}{l}\text { ellow } \\
\text { sagulated }\end{array}$ & $\begin{array}{l}220 \\
130\end{array}$ & $\begin{array}{l}\text { Pandy } \\
\text { Pandy }\end{array}$ \\
\hline $\begin{array}{l}\text { loody, xanthochromic } \\
\text { roin positive }\end{array}$ & 300 & \\
\hline $\begin{array}{l}\text { loody } \\
\text { hree months later clear }\end{array}$ & $\begin{array}{l}330 \\
150\end{array}$ & 38 \\
\hline $\begin{array}{l}\text { ellow, } \\
\text { sagulated }\end{array}$ & $\begin{array}{l}\text { Ventricular fluid } \\
\text { Spinal fluid }\end{array}$ & $d, 180$ \\
\hline ellow & $\begin{array}{l}\text { Cisternal fluid } \\
290\end{array}$ & 160 \\
\hline ellow & 300 & \\
\hline anthochromic & & 180 \\
\hline $\begin{array}{l}\text { anthochromic } \\
\text { roin positive }\end{array}$ & 50 & 10,500 \\
\hline lear & $\begin{array}{l}\text { Cisternal fuid } \\
470\end{array}$ & 1,100 \\
\hline ellow & 325 & 425 \\
\hline $\begin{array}{l}\text { anthochromic, } \\
\text { san }\end{array}$ & Cisternal fluid & $\begin{array}{l}1,000 \\
48\end{array}$ \\
\hline inthochromic, coagulated & $\begin{array}{l}460 \\
\text { Cisternal fluid }\end{array}$ & $\begin{array}{l}3,000 \\
1,000\end{array}$ \\
\hline eenish-yellow & $\begin{array}{l}200 \\
\text { Ventricular fuid }\end{array}$ & ${ }_{120}^{50}$ \\
\hline
\end{tabular}

nthochromic

nthochromic

ody

thochromic

athochromic

nthochromic, cloudy

xanthochromic

xanthochromic

'thochromic,

gulated

ve tumour:

ar

thochromic, bloody

\section{0}

$190 \quad 60$

220190

$550 \quad 750$

Ventricular fluid

100

$\begin{array}{ll}\text { Cisternal fluid } & 2,400 \\ & 108 \\ \text { Cisternal fluid } & \\ & 288 \\ & 192\end{array}$

1,200

Ventricular fluid 328

$140 \quad 47$

High $\quad 460$

$360 \quad 360$
Radiographic Findings

Site Diagnosis
of Tumour

C7-T6 Granuloma, luetic (?)

P.E.G. slightly dilated ventricles

L1-L4 Ependymoma

L2 Ependymoma

Separation of sutures, decalcification of sella, ventriculogram: hydrocephalus

Slight dilatation of ventricles

'Leptomeningitis' on cerebellar exploration

T12 Oligodendroglioma

T9-L3 Ependymoma

Normal

T3

Neurolemmoma

Ventriculogram normal

L1-L2 Ependymoma

L2-L4 Ependymoma

T12-L21 Neuroma

Skull films normal; vertebral arteriogram normal; cisterns. P.E.G., symmetrically enlarged ventricles

Ventriculogram: symmetrical hydrocephalus

T10-T11

Spongioblastoma

Spreading of sutures, digital markings;

Ventriculogram: mild dilatation of all ventricles

T10-T12

Medulloblastoma

L2

Neurofibroma

Digital impressions, spreading of sutures;

L1 Ependymoblastoma

ventricles

Skull normal

T12-L4

Myxopapilloependymoma

Cisternal P.E.G., hydrocephalus

T5-T

Meningioma

L2-L5 Meninginma

T10-S2 Ependymoma

Carotid arteriogram, stretched vessels :

Ventriculogram, dilated ventricles;

Suboccipital craniotomy, fibrous band at

cisterna, no obstruction

Erosion of dorsum sellae. Ventriculogram,

hydrocephalus

Necropsy, basal adhesive arachnoiditis

Digital markings, arteriogram, stretching of

vessels;

P.E.G., dilatation of ventricles 
TABLE II

FREQUENCY OF CEREBRAL SYMPTOMS AND FINDINGS Symptoms Findings

\begin{tabular}{lrlr}
\hline Headache & 12 & Papilloedema & 19 \\
Vomiting & 6 & Retinal haemorrhage & 12 \\
Diplopia & 5 & Abducens palsy & 4 \\
Blurred vision & 4 & Nystagmus & 2 \\
Failure of vision & 2 & Diminished visual acuity & 1
\end{tabular}

from $47 \mathrm{mg} . \%$ to $180 \mathrm{mg} . \%$ with an average of $112 \mathrm{mg} . \%$. Cisternal fluid samples were recorded as follows: two pressure readings were reported at $290 \mathrm{~mm}$. and $470 \mathrm{~mm}$. of water. The fluid was colourless in three, yellow in one, and xanthochromic in two cases. Protein content ranged from $48 \mathrm{mg}$. $\%$ to $1,100 \mathrm{mg}$. \%, an average of $413 \mathrm{mg} . \%$.

Spinal fluid Pressure readings were recorded in 11 cases and in 10 were elevated above $150 \mathrm{~mm}$. reaching as high as $550 \mathrm{~mm}$. The colour of the fluid was yellow in five, xanthochromic in 11, and bloody in three. A positive Froin syndrome was present in six cases. Protein recordings were obtained in 14 cases ranging from $50 \mathrm{mg} . \%$ up to $10,500 \mathrm{mg}$. $\%$.

LOCATION AND DIAGNOSIS OF TUMOUR Table III demonstrates the incidence of their location within the spinal canal and the representation of their histological nature. In the histological distribution a striking feature is the presence of 14 tumours of glial origin and one medulloblastoma. More than half of the total number of tumours were ependymomas. In one case of the luetic granuloma, the histological diagnosis was questioned by other authors (Rohr and Hoffmann, 1959) and considered an atypical neuroma.

\section{TABLE III}

LOCATION AND DIAGNOSIS OF INTRASPINAL TUMOURS

\begin{tabular}{lllr} 
Site & \multicolumn{3}{c}{ Diagnosis } \\
\hline Thoracic 1-6 & 3 & Ependymoma & 11 \\
Thoracic 7-12 & 4 & Astrocytoma & 1 \\
Thoraco-lumbar & 5 & Oligodendroglioma & 1 \\
Lumbar & 9 & Spongioblastoma & 1 \\
& & Medulloblastoma & 1 \\
& & Neurofibroma & 3 \\
\multicolumn{1}{l}{ Total } & & Meningioma & 1 \\
& & Granuloma (luetic) & 1 \\
& $21^{1}$ & Total & 20
\end{tabular}

${ }^{1}$ Two separate tumours in one patient.

\section{DISCUSSION}

The case reported here was the only astrocytoma in the series. Astrocytomas of the spinal cord in children represent about $14 \%$ of all spinal tumours (Rand and Rand, 1960; Ingraham and Matson, 1954; Dodge, Keith, and Campagna, 1956). Nittner
(1956) quoted $15 \%$ of 250 spinal lesions occurring i children and adolescents, of which 11 were intrz medullary gliomas.

The prevalence of ependymomas among intra spinal tumours is confirmed by Lombardi anf Passerini (1961), Turnbull (1962), and Norstrom Kernohan, and Love (1961). The latter indicate $\$$ also that $6 \%$ of all spinal cord tumours are locate $\$$. in the filum and conus medullaris and that $50 \%$ of a $\overline{\mathrm{m}}$ intraspinal gliomas occur in this locale.

The history of trauma preceding the appearance of symptoms of a spinal cord tumour is not infre? quent and was mentioned by Rand and Rand (1960) They also emphasize the presence of scoliosis wit astrocytomas, ganglioneuromas, and extradura cysts.

Rand and Rand stated the average survival tims of patients with astrocytomas as six years, considerably shorter than with ependymomas of the spinal cord. As exceptions they referred to a case of spinat cord glioma where the patient is still living 10 years? after surgery and a 14-year-long history (case 3) of thoracic astrocytoma. The patient described in the report has a similar history and represents an uns usually long survival for this type of tumour? Norstrom et al. (1961) in their series emphasized The longevity with ependymomas of the spinal cord 3 gave their average of survival as 10 years compaged with seven years for astrocytomas. An extremely long period of survival and cure is reported by Love anp Rivers (1962a) for an oligodendroglioma of sho cervical cord.

The spinal fluid protein level when recorded elevated in all cases. The variance of the figures an\$ the small number of cases under consideration, how ever, do not furnish any valuable conclusions as to the average protein content in reference to the locas tion of the tumour. Love and Rivers (1962b) in a evaluation of cerebrospinal fluid protein values if 514 spinal cord tumours showed definite increases of its average content the further caudally the tumoum was located in the spinal canal, with the exception of the sacral area. The average protein content found with astrocytomas was definitely higher than with ependymomas regardless of their location in the spine. If one ignores the few unusually high figures from this small series then the average protei content follows a similar pattern.

Abbott (1939) was the first to describe symptoms of acute headache and backache caused by spinal subarachnoid haemorrhage. Krayenbühl's (1947) case had symptoms of sudden spinal cord compress sion caused by spontaneous haemorrhage. Finche (1951) described the syndrome of spinal subaracho noid haemorrhage associated with spinal tumouf based on several cases. This syndrome was mert 
tioned by Henson and Croft (1956), Mendelsohn and Mora (1958), and Rand and Rand (1960) in the discussion of ependymomas, in the case of spinal fibroblastoma and a sarcoma (Tarlov and Keener, 1953). Although blood was found in the spinal fluid in the case reported, the symptoms as described above were absent.

Several factors were considered responsible for the increased intracranial pressure associated with tumours of the spinal cord. According to Schaltenbrand (1951), disturbance in the spinal fluid circulation occurs in all spinal cord tumours after they reach a certain size; however, this is unrelated to the location of the tumour and regardless of whether the tumour is intra- or extramedullary. Caudal to the tumour the spinal fluid block creates Sperrliquor with its increased protein. The increased protein content, together with a block in the spinal fluid circulation at the site of the tumour, was considered responsible for the symptom by Love, Wagner, and Woltman (1951). The theory of an elevated protein content increasing the viscosity of the spinal fluid and thereby decreasing its absorption is supported by Schaltenbrand (1953) and others (Jentzer, Kessel, and Bonnant, 1952; Rovetta, 1957; Teng, Wagner, and Buxbaum, 1960). Gardner, Spitler, and Whitten (1954) produced the hypothesis that protein molecules leading to mechanical clogging of the 'pores of the semipermeable membrane', which is responsible for the absorption of the cerebrospinal fluid, causes increased pressure. Pressure on the dilated and stagnant subarachnoid veins lead to changes in the permeability of the vessels and to transudate which in turn produces protein changes above the tumour. The possible compression of the spinal venous plexus (Beduschi, Columella, and Papo, 1955) and the venous medullary plexus (Rudnicki and Lebkowski, 1951), leading to the elevation of the venous intracranial pressure and subsequent interference with the absorption of cerebrospinal fluid, are considered. The increased protein content within the intracranial space is probably ultimately responsible for the occurrence of papilloedema. This is exemplified by the elevated protein in the examination of cisternal and ventricular fluid in several reports. High protein levels are responsible for the disturbance in the balance of cerebrospinal fluid secretion and absorption and ultimately leads to delayed resorption.

Spinal fluid drainage (Schaltenbrand and Wördehoff, 1947) into the root sleeve is interfered with by the increase in protein. It is thought that a slow absorption occurs via the perineural spaces ultimately draining into the lymphatic system. According to Wustmann (1953), the largest and most important drainage within the spine is the dorsal part of the terminal conus. Others consider the spinal subarachnoid space to play a minor role in the absorption of cerebrospinal fluid. This might, however, in the presence of other factors be contributory.

Harris (1962) concluded in his observation, especially of acoustic neuromas and choroid plexus papilloma, that protein transudates from these neoplasms may cause inflammatory reaction especially involving the basal leptomeninges. This appeared to be an individual response, possibly allergic. He also accepted the factors cited above and mentioned as an additional cause bleeding in the subarachnoid space responsible for leptomeningitic fibrosis and the development of communicating hydrocephalus. The persistent stimulus to produce cerebrospinal fluid is determined by increased protein content (Rovetta, 1957). In this hypothesis the pathogenetic mechanism of hydrocephalus is similar to that of subacute or chronic choroido-ependymitis. Mucinous material may be produced as a result of degeneration of the tumour which increases the spinal fluid protein and affects the absorption (Teng et. al., 1960). Weickmann (1954) referred to toxic and inflammatory components aiding in the disturbance of the balance of secretion and absorption of cerebrospinal fluid. He also stressed the 'vegetative labile personality' as an additional factor and supports this by citing cases in which papilloedema followed spinal anaesthesia.

\section{COMMENT}

The development of papilloedema in the GuillainBarré syndrome (Drew and Magee, 1951; DennyBrown, 1952) and in the convalescent state following poliomyelitis (Weiman, McDowell, and Plum, 1951; Taylor and Collier, 1901) in which the spinal fluid protein level is elevated, lead to the final conclusion that the increased protein content also plays a major role in cases of spinal cord tumours associated with increased intracranial pressure. With the elevated protein are associated the delayed cerebrospinal fluid absorption, the stasis of the spinal venous plexus, the possible toxic effect, and the leptomeningitic reaction. Whether in fact tumours produce degenerative material or have a direct stimulating effect on the production of cerebrospinal fluid is not established but may be considered. The absorptive ability of the spinal subarachnoid space and the root sleeve probably has been overrated in the past but can certainly add to the other factors. There remains the question of whether the labile personality together with other unknown factors attribute to the described syndrome.

That the protein content or the location of the tumour are not the only factors in producing increased intracranial pressure is supported by the rarity of its occurrence considering the large series of spinal cord tumours without that complication. For 
instance, Rudnicki and Lebkowski (1951) found only one case among 109 spinal cord tumours and in the series of 100 spinal cord tumours reported by Norstrom et al. (1961) three cases were disclosed.

If one considers the reported case in the light of the above we find several factors consistent. A spinal fluid block was demonstrated by myelography and at surgery. The pressure of the cerebrospinal fluid and its protein were elevated, although the values were less than in many other cases. The tumour was located in the thoraco-lumbar or conus area where supposedly most of the intraspinal absorption of cerebrospinal fluid takes place. The marked kyphosis might be considered as an added mechanical factor in the obstruction of the flow of cerebrospinal fluid. The tumour was slow growing, soft and degnerated, and contained bloody cysts. The presence of blood in the cerebrospinal fluid could be attributed to the puncture of a cyst at the time of procedure rather than to a spontaneous bleed since referable symptoms were lacking. In support of Weickmann, the patient was a rather fragile, fair-skinned and redhaired girl.

It is noteworthy that in many cases reported the symptoms of increased intracranial pressure disappeared within a short period following surgery for complete or only partial removal of the tumour. This can be explained either by the removal of the tumour itself or the relief of the obstruction to the flow of the spinal fluid and its consequences. As in this case, only very little tumour was removed but the dura was left open and later radiation therapy was added. Not only did the cranial symptoms disappear, but also the cerebrospinal fluid findings improved.

\section{SUMMARY}

A case of an astrocytoma of the thoraco-lumbar spine associated with signs and symptoms of increased intracranial pressure in a 15 -year-old girl is reported. This also represents a recurrence of the tumour after 14 years.

The literature was reviewed and 19 reports associated with the syndrome of increased intracranial pressure were found. The important data are summarized and analysed, and pertinent features of these cases are discussed.

Several aetiological factors considered responsible in producing this syndrome are asserted. The increased protein content of the cerebrospinal fluid appears to be the main factor in the development of this syndrome. In addition, however, the presence of blood, inflammatory reaction of the meninge degenerative products of the tumour, obstruction the site of intraspinal cerebrospinal fluid drainage and possibly other unknown factors have to be cops sidered. A final comment referable to the case undeo these considerations is made.

I wish to thank Dr. James D. Humes, U.S.N. Departme of Pathology, who reviewed and supplied the pathologica material.

\section{REFERENCES}

Abbott, K. H. (1939). Bull. Los Angeles neurol. Soc., 4, 127.

Beduschi, A., Columella, F., and Papo, I. (1955). Chirurgia (Milană 10,310 .

Cecotto, C., and Mingrino, S. (1959). Acta chir. ital., 15, 977.

Denny-Brown, D. E. (1952). New Engl. J. Med., 246, 839.

Dodge, H. W. Jr., Keith, H. M., and Campagna, M. J. (1956). ठ int. Coll. Surg., 26, 199.

Drew, A. L., and Magee, K. R. (1951). Arch. Neurol. Psychiat. (Chic $\overrightarrow{\text { ) }}$ 66, 744.

Farnarier, G., Roger, J., and Vigouroux, R. (1957). Rev. Oto-neuro ophtal, 29, 490.

Fincher, E. F. (1951). J. Neurosurg., 8, 576.

Gardner, W. J., Spitler, D. K., and Whitten, C. (1954). New Engl J. Med., 250, 932.

Halpern, L., Feldman, S., and Peyser, E. (1958). A.M.A. Arch Neurol. Psychiat., 79, 138.

Harris, P. (1962). Develop. med. Child Neurol., 4, 270.

Henson, R. A., and Croft, P. B. (1956). Quart. J. Med., 25, 53. $\vec{D}$

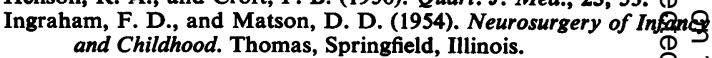

Jentzer, A., Kessel, K., and Bonnant, M. (1952). Rev. neurol., 87, .028. Kyrieleis, W. (1931). Die Augenveränderungen bei den entznüdlishọ Erkrankungen des Zentralnervensystems. In Kurzes Handbuê. der Ophthalmologie, edited by F. Schieck and A. Brüch̆gę vol. 6, p. 669. Springer, Berlin.

Krayenbühl, H. (1947). Schweiz. med Wschr., 77, 692.

Lombardi, G., and Passerini, A. (1961). Radiology, 76, 381.

Love, J. G., and Rivers, M. H. (1962a). Minn. Med., 45, 37. (1962b). J. Neurosurg., 19, 906.

Wagner, H. P., and Woltman, H. W. (1951). Arch. Neuret Psychiat., 66, 171.

Mendelsohn, R. A., and Mora, F. (1958). J. Neurosurg., 15, 460.

Nittner, K. (1956). Zbl. Neurochir., 16, 348.

Norstrom, C. W., Kernohan, J. W., and Love, J. G. (1961). J. Amê

med. Ass., 178, 1071.
Rand, R. W., and Rand, C. W. (1960). Intraspinal Tumours of Chim hood. Thomas, Springfield, Illinois.

Rohr, H., and Hoffmann, W. (1959). Nervenarzt, 30, 391.

Rovetta, P. (1957). Arch. Neurochirug., 3, 317.

Rudnicki, S., and Lebkowski, J. (1951). Neurol. Neurochir. Psychiă. pol., 1, 49.

Schaltenbrand, G. (1951). Die Nervenkrankheiten. Thieme, Stuttoget (1953). Lancet, 1, 805.

and Wördehoff, P. (1947). Nervenarzt, 18, 548.

Tarlov, I. M., and Keener, E. B. (1953). Neurology (Minneap.), 3, 38.

Taylor, J., and Collier, J. (1901). Brain, 24, 532.

Teng, P., Wagner, J. H., and Buxbaum, M. W. (1960). A.M.A. Ark. Neurol., 2, 657.

Turnbull, F. (1962). Clin. Neurosurg., 8, 237-247.

Weickmann, F. (1954). Nervenarzt, 25, 65.

Weiman, C. G., McDowell, F. H., and Plum, F. (1951). Arch. NeurD. Psychiat., 66, 722.

Wustmann, O. (1953). Zbl. Chir., 78, 1297.

Zeitlin, R. (1937). Ueber einen Fall von extramedulaerer Rueckenmarksgeschwulst mit Stauungspapille. Dissertation. Hambute. 